\title{
Clinical Trial Site Training Material
}

National Cancer Institute

\section{Source}

National Cancer Institute. Clinical Trial Site Training Material. NCI Thesaurus. Code C115604.

A collection of materials used to train site personnel selected for a clinical trial. 